\title{
Kształtowanie nazewnictwa ulic toruńskiego osiedla Bielany w dwudziestoleciu międzywojennym*
}

Włodzimierz Ignacy Deczyński**

Rok 1920 to data, kiedy po raz pierwszy w historii Torunia drogi, ulice i place uzyskały wyłącznie polskie nazwy. Proces polonizacji nazw toruńskich ulic rozpoczął się już 18 stycznia 1920 r., a więc w dniu wkroczenia wojsk polskich do miasta. Jak wspominała Helena Steinbornowa (przewodnicząca komisji przyjęcia wojsk polskich w Toruniu), ,[...] grupa harcerzy rozlepiła plakaty z polskimi nazwami ulic na razie tylko w thumaczeniu" ". Jeszcze tego samego roku dokonano przemianowania ulic w Toruniu podczas akcji „przemalowania niemieckich nazw na polskie"2.

\footnotetext{
${ }^{*} \mathrm{~W}$ artykule wykorzystano obszerne fragmenty pracy licencjackiej autora pod tytułem: „Kształtowanie nazewnictwa istniejących i nowo powstałych ulic toruńskiego osiedla Bielany w dwudziestoleciu międzywojennym". Jak dotąd, nie ukazało się opracowanie problematyki polskiego nazewnictwa ulic Torunia z lat 1920-1939. Artykuł, podobnie jak praca licencjacka, dotyczy nazewnictwa ulic osiedla Bielany w okresie dwudziestolecia międzywojennego.

${ }^{* *}$ Kolekcjoner, historyk, absolwent Wydziału Nauk Historycznych Uniwersytetu Mikołaja Kopernika w Toruniu. Licencjat uzyskany w 2018 r. na podstawie pracy: „Kształtowanie nazewnictwa istniejących i nowo powstałych ulic toruńskiego osiedla Bielany w dwudziestoleciu międzywojennym", pod naukową opieką prof. dr. hab. Krzysztofa Mikulskiego. Zainteresowania: historia Torunia i regionu.

${ }^{1}$ M. Wojciechowski, Przejęcie Torunia przez władze polskie w styczniu 1920 roku, [w:] Historia Torunia, t. III, cz. II: W czasach Polski Odrodzonej i okupacji niemieckiej (1920-1945), pod red. M. Biskupa, Toruń 2006, s. 9.

${ }^{2}$ Archiwum Państwowe w Toruniu, Akta miasta Torunia (dalej cyt. APT, AmT), sygn. D 2967, Przemalowanie nazw niemieckich na polskie; zob. też k. 20 - wniosek
} 
Pojawienie się tablic z polskimi nazwami ulic było widocznym świadectwem funkcjonowania nowej polskiej władzy w mieście. Ulice i place w Toruniu od czasu odzyskania niepodległości otrzymywały polskie nazwy o wyraźnym patriotycznym i dydaktycznym przesłaniu. Nadawane nazwy powiązane były często z wydarzeniami historycznymi, postaciami zasłużonymi dla polskiej kultury, historii, polityki i walk narodowowyzwoleńczych. Było to zrozumiałe w kontekście eksponowania polskości miasta odzyskanego po 127 latach zależności od niemieckich Prus. Helena Piskorska, zasłużona archiwistka miejska, z której wiedzy i doświadczenia wielokrotnie korzystano w procesie nazywania torunskich ulic, pisała: ,[...] przy nadawaniu nazw ulicom miasta Torunia kierowano się zasadą, aby: zachować nazwy średniowieczne, nadawać ulicom nazwy wodzów narodu tak na polu politycznym (Batory, Sobieski itp.), jak kulturalnym (Kochanowski, Konopnicka itp.), oraz nazwiska wybitnych toruńczyków zasłużonych około miasta"3.

Powstawanie nowych dróg i ulic w Toruniu powiązane było ściśle z rozbudową miasta, szczególnie po 1930 r. Miało na to wpływ kilka zasadniczych czynników. Jednym z najważniejszych była decyzja o ustanowieniu Torunia stolicą województwa pomorskiego. Stołeczność Torunia przyciągała dużą liczbę pracowników liczących na możliwości osiedlenia się i zdobycia tutaj pracy. $Z$ niewielkiego przygranicznego miasta-twierdzy, jakim był Toruń w okresie pruskiej zależności, w dwudziestoleciu międzywojennym miasto przerodziło się w centrum polityczne i kulturalne oddziałujące nie tylko na region, ale także na inne części odrodzonej ojczyzny ${ }^{4}$. Populacja Torunia w latach 1920-1938 wzrosła ponad dwukrotnie. W roku 1920 miasto liczyło ledwie 37,3 tys. mieszkańców, a w 1938 r. już blisko 75,9 tys. ${ }^{5}$ Napływ tak wielu nowych

Jakuba Suleckiego (członka Rady Miejskiej) z dnia 4 sierpnia 1920 r. o następującej treści: „Niniejszym stawiam wniosek nagły: rozpisanie prac celem zmiany nazw ulic w jak najkrótszym czasie uskutecznić". Celem tych działań było szybkie spolonizowanie całej przestrzeni społecznej odzyskanego miasta, w tym także nazw ulic miasta Torunia.

${ }_{3}^{3}$ Pismo Heleny Piskorskiej z 39 września 1933 r., APT, AmT, sygn. D 2900, Sprawozdania o ruchu budowlanym, k. 42.

${ }^{4}$ P. Zieliński, Rola Torunia i Pomorza w okresie interwencjonizmu państwowego 1936-1939 w świetle publicystyki, Rocznik Toruński, t. 40: 2013, s. 77.

${ }^{5}$ R. Sudziński, Spoleczeństwo międzywojennego Torunia, [w:] Historia Torunia, t. III, cz. II, s. 44. 
mieszkańców zmuszał władze miasta do zajęcia się problemem mieszkaniowym. Priorytetowym zadaniem stało się przygotowanie terenów przeznaczonych na budownictwo mieszkaniowe, a w konsekwencji wytyczenie nowych ulic, którym należało nadać urzędowe nazwy.

Istotnym czynnikiem inspirującym ruch budowlany w Toruniu były także ustawowe regulacje dotyczące rozbudowy ważniejszych miast odrodzonej Rzeczypospolitej. Na mocy rozporządzenia prezydenta Polski z dnia 22 kwietnia $1927 \mathrm{r}$. „O rozbudowie miast” powołane zostały komitety rozbudowy ośrodków miejskich złożone z inżynierów, architektów i urbanistów. Zadaniem komitetów było nie tylko zapobieganie problemowi niedoboru mieszkań, ale również inicjowanie, wspieranie i stwarzanie odpowiednich warunków do racjonalnych inwestycji budowlanych w miastach. W ten sposób centralne władze obligowały samorządy miast do akcji mających na celu ożywienie ruchu budowlanego, rozbudowę infrastruktury miejskiej, tworzenie odpowiednich narzędzi i zachęt do inwestowania w budownictwo mieszkaniowe. Aby urzeczywistnić ten program, władze miast zostały zobowiązane do pomocy spółdzielniom mieszkaniowym, instytucjom społecznym oraz osobom fizycznym w budowie domów mieszkalnych poprzez odstępowanie parceli budowlanych, a także ułatwianie sfinansowania budownictwa mieszkaniowego. Ważną misją samorządów odrodzonej Rzeczypospolitej było również prowadzenie samodzielnej akcji budowlanej ${ }^{7}$. Władze miast zobowiązane zostały do budowy nowych domów mieszkalnych (głównie na potrzeby najuboższej warstwy społecznej: bezrobotnych i bezdomnych) oraz do produkcji i zakupu materiałów budowlanych ${ }^{8}$.

Już w 1926 r., w celu pobudzenia prywatnego ruchu budowlanego, Magistrat Torunia podjął uchwałę o oddaniu części gruntów miejskich pod budowę domów mieszkalnych bezpłatnie lub po bardzo niskiej cenie. W ciągu zaledwie kilku lat, dzięki akcji zagospodarowywania pustych obszarów, budynkami o charakterze wielorodzinnym i willowym zostały zabudowane liczne wolne miejsca w środkowych dzielnicach

\footnotetext{
${ }^{6}$ Dziennik Ustaw (dalej cyt. DzU), nr 42 z 22 kwietnia 1927 r., poz. 372, O rozbudowie miast, art. 2 i 3.

${ }^{7}$ APT, AmT, sygn. D 2902, Statystyka ruchu budowlanego, k. 128-131.

${ }^{8} \mathrm{DzU}, \mathrm{nr} 42$, art. 4, pkt. 2.
} 
miasta. Na peryferiach zaś budowano niewielkie i tanie $\mathrm{w}$ realizacji domy jednorodzinne ${ }^{9}$. Z szerokiego i ambitnego programu budowlanego w tym czasie korzystało w Toruniu wielu lokalnych i pochodzących z zewnątrz inwestorów: spółdzielni mieszkaniowych, towarzystw budowlanych i osób prywatnych ${ }^{10}$. Bezpłatne przekazywanie działek na potrzeby budownictwa mieszkaniowego obwarowane było jednak wieloma ograniczeniami. Jednym $\mathrm{z}$ nich był obowiązek rozpoczęcia budowy domu w ciągu jednego miesiąca i doprowadzenie do stanu „pod dach" w terminie jednego roku od daty przekazania działki. Kolejnym warunkiem był obowiązek korzystania z lokalnych firm, miejscowych robotników i rzemieślników. Poza tym inwestorzy otrzymujący bezpłatne działki budowlane zostali zobowiązani do wynajęcia dotychczas najmowanego lokalu mieszkalnego urzędnikom przeprowadzającym się do Torunia (za najem płacono odpowiedni czynsz uzgodniony z Magistratem). Na koniec inwestor bywał pouczony, że w przypadku niedotrzymania choćby jednego $z$ tych warunków mógł być narażony na utratę nie tylko przydzielonej bezpłatnie działki, ale także poczynionych na niej nakładów inwestycyjnych ${ }^{11}$.

Znaczącym czynnikiem motywującym rozbudowę Torunia $\mathrm{w}$ omawianym okresie były również starania władz miasta o utrzymanie $\mathrm{w}$ Toruniu stolicy województwa. Leżąca nieopodal Bydgoszcz, jako były pruski ośrodek administracyjny, ale też silny organizm gospodarczy, przez cały prawie okres dwudziestolecia międzywojennego wysuwała postulaty ulokowania siedziby województwa pomorskiego u siebie. Stawianie na dynamiczny rozwój Torunia było słusznym przeciwdziałaniem wobec tych zakusów, ponieważ aż do końca dwudziestolecia międzywojennego Toruń utrzymał pozycję politycznego centrum Pomorza.

${ }^{9}$ K. Przybyszewski, Rozbudowa miasta Torunia w latach 1920-1939, Acta Universitatis Nicolai Copernici, Historia XI - Nauki Humanistyczno-Społeczne, z. 74, 1977, s. 139; APT, AmT, sygn. D 2988, Sprzedaż gruntów pod budowę domów mieszkalnych, k. 1-191.

${ }^{10}$ APT, AmT, sygn. D 3006, Przydział gruntu - Osiedle wojskowe, k. 1-48; ibid., sygn. D 3010, Przydział gruntu, Stowarzyszenie popierania budowy domów dla pracowników umysłowych, k. 1-82.

${ }^{11}$ APT, AmT, sygn. D 2988, Sprzedaż gruntów, k. 162. 
W omawianym okresie pojawił się problem nieoznakowanych, bezimiennych oraz nowo utworzonych $\mathrm{w}$ tym czasie ulic. Zjawisko to nasiliło się wraz z wydzieleniem i zabudową nowych dzielnic miasta, w tym także omawianego obszaru dzielnicy Bielany.

Niedogodności związane $\mathrm{z}$ nieuporządkowaną przestrzenią miasta zgłaszane były wielokrotnie przez mieszkańców, różne instytucje i urzędy, spółdzielnie mieszkaniowe i stowarzyszenia budujące domy ${ }^{12}$. W aktach Wydziału Budowlanego Magistratu miasta Torunia natrafić można na wiele dokumentów, w których podnoszona była kwestia nieoznaczenia ulic i numeracji domów. Przykładem może tu być pismo Towarzystwa Popierania Budowy Domów Własnych skierowane do Zarządu Miasta Torunia z prośbą ,,[...] o nadanie ulicom na osiedlu między Koszarową [dzisiejsza Broniewskiego], nazw i numeracji”. Dalej czytamy, że brak oznaczenia ulic i domów powoduje ,[...] niesłychane zamieszanie $\mathrm{w}$ porozumieniu się z mieszkańcami tej dzielnicy, a szczególnie przy doręczaniu przez pocztę, urzędy państwowe i firmy handlowe listów, dokumentów urzędowych i innych przesyłek". Podkreśla się przy tym, że „[...] wszyscy mieszkańcy tej dzielnicy nie mogą zrozumieć, jakie przeszkody uniemożliwiają wykonanie tak łatwej czynności administracyjnej [...], a nie może doczekać się pomyślnego rozstrzygnięcia przez organy miasta Torunia od kilku miesięcy". Na koniec autorzy tego pisma proszą ,[...] aby ostatecznie tę sprawę uregulowano w najkrótszym czasie, względnie, aby wskazano, celem uspokojenia niesłychanie rozgoryczonych mieszkańców [...], dlaczego tak łatwa sprawa przez tak długi przeciąg czasu nie może być załatwiona"13.

Można domniemywać, że wskutek skarg mieszkańców, 12 maja 1931 r. wojewoda pomorski wydał rozporządzenie „O ewidencji i kontroli ruchu ludności”, które miało na celu między innymi administra-

\footnotetext{
12 Zob. pismo Towarzystwa Popierania Budowy Domów Własnych z dnia 2 VII 1931 r. skierowane do Zarządu Miasta Torunia, APT, AmT, sygn. D 2969, Nazwy ulic, placów i numery orientacyjne, k. 36; zob. też pismo z dnia 4 czerwca 1926 r., sygn. D 2968, Sprawy uporządkowania nazw ulic, placów i dróg oraz numerów orientacyjnych w obrębie miasta Torunia, k. 136, w którym zgłasza się, że: „widnieją jeszcze w mieście Toruniu ulice bez nazwy, a mianowicie w kolonii na Bielanach, po prawej stronie ulicy Grunwaldzkiej”.

${ }^{13}$ APT, AmT, sygn. D 2969, Nazwy ulic, placów, k. 37.
} 
cyjne uporządkowanie przestrzeni miast na terenie województwa pomorskiego ${ }^{14}$. Przepis głosił, że „w gminach miejskich, wszystkie ulice i place winny posiadać nazwy organizacyjne". Ponadto wojewoda zarządził, że „wszystkie budynki przeznaczone w całości lub częściowo na pobyt ludzi [...] podlegają kolejnej numeracji”. Dalej wojewoda zobowiązał zarządy gmin do ,zaprowadzenia i utrzymywania w stanie aktualności ewidencję ulic i placów publicznych w miejscowościach". Polecił też, ,żeby nazwy ulic i placów [...] w gminach miejskich ustalały korporacje miejskie” oraz, aby „nowo powstałym arteriom komunikacyjnym nadać nazwy równocześnie z definitywnym ich wytyczeniem”. Poza tym „nazwy ulic i placów [...] winny być uwidocznione kosztem gminy za pomocą tablic na wszystkich budynkach krańcowych i narożnych, na co właściciele budynków [...] obowiązani są zgodzić się bez jakiegokolwiek odszkodowania". Na koniec wojewoda ustalił termin wykonania czynności opisanych w rozporządzeniu do dnia 1 lipca $1931 \mathrm{r}$.

Dzielnica Bielany położona jest w północno-zachodniej części Torunia. Od zachodu graniczy z Barbarką, od północy z Wrzosami, od wschodu z Przedmieściem Chełmińskim, a od południa z Przedmieściem Bydgoskim. Bielany zostały włączone $\mathrm{w}$ granice administracyjne miasta na przełomie XIX i XX w., jeszcze za panowania pruskiej władzy. Historycznie dzielnica podzielona była na dwie części: północną - Stare Bielany (Weisshof) i południową - Nowe Bielany (Neu Weisshof). Na terenie Starych Bielan zlokalizowany był Folwark Bielany, będący patrymonium Torunia, którego budynki można napotkać jeszcze dzisiaj $^{15}$. W przeszłości tereny położone na Bielanach wykorzystywano głównie rolniczo. Znaczną część tego obszaru zajmowały sady (planty) i uprawy warzyw. Znacznie wcześniej na tych terenach powstawały pierwsze zabudowania, pojedyncze domy i niewielkie kolonie, co można zaobserwować na mapach z XIX i początku XX w. - Kolonie Weisshof $^{16}$. W okresie rozbudowy technicznej infrastruktury miasta, pod ko-

\footnotetext{
${ }^{14}$ Rozporządzenie Wojewody Pomorskiego z dnia 12 maja 1931 r., „O ewidencji i kontroli ruchu ludności”, Pomorski Dziennik Urzędowy nr 11 z dnia 1 czerwca 1931 r., poz. 156; APT, AmT, sygn. D 2968, Sprawy, k. 161,

${ }^{15}$ Obecnie w budynkach dawnego folwarku mieści się Hospicjum Światło.

${ }^{16}$ Plany miasta Torunia $\mathrm{z}$ lat 1901, 1921, 1929, w zbiorach autora.
} 
niec XIX w., na terenie Bielan umiejscowiono Miejski Zakład Wodociągowy, w którego skład wchodziły ujęcie wody, wieża ciśnień i stacja pomp. W latach 1926-1929, na skrzyżowaniu ulic Grunwaldzkiej i św. Józefa, zbudowano klasztor zakonu redemptorystów z przyklasztorną szkołą i tymczasową kaplicą pod wezwaniem św. Józefa. W 1910 r. oddano do użytku linię kolejową biegnącą od Dworca Północnego do nieodległego Czarnowa. Na końcu ulicy Henryka Sienkiewicza położony był Dworzec Szkolny, nazywany też Dworcem Czarnowo ${ }^{17}$. Można zaryzykować tezę, że wymienione obiekty, a także nieodległe szkoły i koszary wojskowe położone przy ulicy Henryka Sienkiewicza, nowe ulice i drogi stanowiące ciągi komunikacyjne łączące Bielany z innymi dzielnicami czy w końcu linia kolejowa wraz z dworcami: Północnym i Szkolnym, wpływały na rozwój miasta, przyczyniając się w ten sposób do podjęcia decyzji o przeznaczeniu tego terenu na osiedle mieszkaniowe $^{18}$. Większa intensyfikacja zabudowy tego kwartału nastąpiła dopiero na początku lat trzydziestych XX w. Wówczas to wytyczono nowe ulice, a sektory budowlane podzielono na parcele ${ }^{19}$. Osią komunikacji północ-południe była droga biegnąca wzdłuż toru kolejowego prowadzącego od Dworca Północnego do Dworca Szkolnego (dzisiejsza ulica św. Józefa). Natomiast osiami wschód-zachód były ulice: Grunwaldzka, Józefa Wybickiego i utworzona na początku lat trzydziestych ulica Żwirki i Wigury. Wyodrębniony kwartał zaprojektowano jako dzielnicę mieszkaniową, na której planowano budowę niewielkich domów jednorodzinnych. Ustalono kubaturę domów na około 500 metrów sześciennych. Zabudowa dzielnicy miała mieć półzwarty

\footnotetext{
${ }^{17}$ Dworzec zlikwidowano pod koniec lat $60 . \mathrm{XX}$ w. w ramach rozbudowy obiektów Uniwersytetu Mikołaja Kopernika. Na miejscu dworca znajduje się obecnie Studencki Klub Od Nowa.

${ }^{18}$ J.Salm, Przemiany przestrzenne pruskiego Torunia, [w:] Historia Torunia, t. III, cz. I: W czasach zaboru pruskiego (1793-1920), pod red. M. Biskupa, Toruń 2003, s. 91; R. Sudziński, Infrastruktura i gospodarka komunalna międzywojennego Torunia, [w]: Historia Torunia, t. III, cz. II, s. 123; APT, AmT, sygn. G 1218, Klasztor Redemptorystów, Św. Józefa 29,31,33,35, k. 1-92; ibid., sygn. D 1331, Wydział Prezydialny, k. 241; M. Niedzielska, Życie polityczne i kulturalne Torunia (1815-1914), [w:] Historia Torunia, t. III, cz. I, s. 223, 224.

${ }^{19}$ Zob. mapa, APT, AmT, sygn. D 2969, Nazwy ulic, k. 78; sygn. D 3006, Przydział gruntu, k. 8; sygn. D 3010, Przydział gruntu, Stowarzyszenie, cały poszyt.
} 
i luźny charakter, a domy miały być budynkami bliźniaczymi lub wolno stojącymi, z dwiema kondygnacjami: parterem i piętrem oraz piwnicą ${ }^{20}$. Wielkość wytyczonych działek mieściła się w granicach 500600 metrów kwadratowych. Teren został uzbrojony w instalację wodociągową i kanalizacyjną za odpłatnością 80 zł od jednego metra bieżącego frontu działki. Zasadą bowiem było, że Magistrat nie wydawał pozwolenia na budowę, zanim działki nie zostały uzbrojone w podstawową infrastrukturę techniczną ${ }^{21}$.

Ulice zlokalizowane na Bielanach, które będą tutaj omawiane, to: Grunwaldzka, Balonowa (wcześniej Lotnicza), św. Józefa, św. Klemensa, Kaszubska, Borowiacka, Żwirki i Wigury, Józefa (Montwiłła) Mireckiego, Bronisława Pierackiego (dzisiejsza Stefana Jaracza), Wodociągowa, Koniuchy, Józefa Wybickiego i Warmińska. Ulice te otrzymały swoje urzędowe nazwy w latach 1920-1934.

Proces nadawania nazw ulicom osiedla Bielany podzielić można na cztery etapy. Pierwsze polskie nazwy ulic w tym kwartale nadane zostały w 1920 r. (tuż po odzyskaniu niepodległości) w ramach akcji „przemalowania nazw niemieckich na polskie”. Druga grupa ulic tego osiedla została nazwana $\mathrm{w}$ trakcie procedury trwającej od czerwca 1926 r. aż do kwietnia 1931 r. Trzecia grupa zyskała nazwy od połowy czerwca do połowy sierpnia 1931 r. Ostatnia grupa ulic osiedla Bielany otrzymała swoje urzędowe nazwy od połowy czerwca 1934 r. do października $1934 \mathrm{r}$.

Pierwszą ulicą osiedla Bielany, która miała polską nazwę, była ulica Grunwaldzka. Nazwa ta pojawiła się w „Spisie ulic polsko-niemieckim miasta Torunia" sporządzonym (prawdopodobnie) w połowie roku 1920. Ulica ta powstała jeszcze w czasie administracji pruskiej i nosiła niemiecką nazwę Janitzenstrasse ${ }^{22}$. Mimo że ulica Grunwaldzka łączyła Szosę Chełmińską z Szosą Okrężną, to praktycznie nigdy nie uzyskała statusu ważnej drogi. Tylko przy początkowym odcinku ulicy, od stro-

\footnotetext{
${ }^{20}$ APT, AmT, sygn. D 3006, Przydział gruntu - Osiedle wojskowe, k. 3; sygn. D 2988, Sprzedaż, k. 36.

${ }^{21}$ Ibid., sygn. D 3010, Przydział gruntu, k. 10, Uchwała Magistratu nr 1010 z 3 listopada $1933 \mathrm{r}$.

${ }^{22}$ Ibid., sygn. D 2967, Przemalowanie nazw, bez paginacji, zob. też Nowy spis ulic miasta Torunia 1920, drukiem Drukarni Robotniczej w Toruniu, bez daty, s. 6 .
} 
ny Szosy Chełmińskiej do ulicy św. Józefa rozwinęło się (nieliczne zresztą) budownictwo mieszkaniowe. Dopiero po II wojnie światowej, w latach pięćdziesiątych i sześćdziesiątych, wschodni odcinek (bliżej skrzyżowania z ulicą św. Józefa) zabudowany został obiektami oświatowymi. Natomiast odcinek od ulicy św. Józefa do Szosy Okrężnej, jak dotąd, nie został wyposażony w odpowiednią infrastrukturę techniczną. Od czasu mianowania ulicy Grunwaldzkiej nazwa jej przetrwała w niezmienionej formie, $\mathrm{z}$ wyjątkiem oczywiście okresu okupacji niemieckiej, kiedy powrócono do pierwotnej nazwy - Janitzenstrasse ${ }^{23}$. Obecnie ulica jest dość dobrze rozpoznawalna przez większość mieszkańców miasta. Ma to niewątpliwie związek ze znajdującymi się przy niej wieloma placówkami edukacyjnymi. Corocznie opuszcza je kilkusetosobowa grupa absolwentów, którzy przechowują w pamięci okres kilkuletniej nauki w tych szkołach.

W połowie 1926 r. do Magistratu Torunia wpłynęło pismo, w którym zgłaszano, że ,[...] w mieście Toruniu istnieją ulice bez nazwy, a mianowicie w kolonii na Bielanach, po prawej stronie ulicy Grunwaldzkiej" ${ }^{24}$. Na polecenie naczelnika wydziału budowlanego Magistratu inż. Kazimierza Ulatowskiego sporządzono wykaz dziesięciu ulic mających jeszcze nazwy niemieckie lub niemających nazw w ogóle. W wykazie tym między innymi wymieniona została ulica łącząca się z ulicą Grunwaldzką (dawne niemieckie nazwy Randweg, Ringweg, Mittelweg). Zaproponowano dla tej ulicy nazwę Niecała (jest to odcinek dzisiejszej ulicy Borowiackiej zaczynający się od strony ulicy Grunwaldzkiej) $)^{25}$.

Drogą, która znalazła się także w tym wykazie, jest dzisiejsza ulica św. Józefa. Opisana została jako: ,„przedłużona ulica Sienkiewicza łącząca Szosę Chełmińską z ulicą Sienkiewicza". Dla tej ulicy zaproponowano wówczas nazwy: Henryka Sienkiewicza lub Fryderyka Skarbka.

\footnotetext{
${ }^{23}$ Strassenverzeichnis der Stadt Thorn, kieszonkowy przewodnik po ulicach Torunia, prawdopodobnie z roku 1940, s. 7 i 14, zbiory autora; zob. też APT, AmT, sygn. E 749, Strassennamenverzeichnis, k. 3. Przywrócenie polskich nazw toruńskich ulic po okresie okupacji nastąpiło przypuszczalnie już w 1945 r.; zob. Plan orientacyjny miasta Torunia z roku $1946 \mathrm{z}$ opisem ulic oraz dodatkowo na odwrocie planu - spisem wszystkich ulic Torunia, zbiory autora.

${ }^{24}$ APT, AmT, sygn. D 2968, Sprawy, k. 136.

${ }^{25}$ Ibid., k. 127,128.
} 
Z niewiadomych powodów do końca 1927 r. sprawa mianowania tych ulic nie była dalej procedowana. Dopiero rok później kontynuowano proces nadawania im nazw. Powołana podkomisja deputacji muzealnej pod przewodnictwem Ottona Steinborna przedłożyła propozycje nazw dla ulic miasta Torunia. Dla dawnej ulicy Ringweg nadal postulowano nazwę: Niecała (Borowiacka). Przedłużenie zaś „ulicy Sienkiewicza, łączące Szosę Chełmińską z ulicą Sienkiewicza”, proponowano nazwać - „Fryderyka Skarbka jako znakomitego pisarza polskiego, rodzonego toruńczyka, urodzonego przy ulicy Mostowej”. Natomiast drogę łączącą Szosę Okólną z ulicą Grunwaldzką (dzisiejsza ulica św. Klemensa) proponowano nazwać imieniem „Jana Rybińskiego najznakomitszego poety polskiego XVI wieku, Pomorzanina, sekretarza Magistratu toruńskiego"26.

Dnia 1 kwietnia 1931 r. Wydział Kultury i Oświaty opracował własną listę nienazwanych ulic osiedla Bielany, dla których postulowano następujące nazwy: dla ulicy od dworca Torun-Czarnowo do Hali Balonowej zaproponowano nazwę ulica Balonowa. Dla ulicy zaczynającej się od toru kolejowego (przecinającego ulicę Balonową), do Grunwaldzkiej, zaproponowano nazwę ulica Saperów, a dla odcinka od Grunwaldzkiej do Szosy Chełmińskiej - ulica Redemptorystów ${ }^{27}$.

Magistrat zaakceptował nazwę ulicy Balonowej, natomiast nazwę ulicy Saperów zmienił na Redemptorystów. Na postulowaną zaś nazwę dla drugiej części drogi (od ulicy Grunwaldzkiej do Szosy Chełmińskiej) Magistrat się nie zgodził. Ten odcinek ulicy nadal pozostał nienazwany. Na koniec Rada Miejska zatwierdziła zaproponowane przez Magistrat nazwy dla wyżej wymienionych ulic ${ }^{28}$.

Nazwa ulicy Balonowej wywodzi się od zbudowanej przez pruskie władze w latach 1909-1910 (na potrzeby twierdzy Toruń) hali dla sterowców (balonów). Po wkroczeniu do Torunia wojsk polskich hala

\footnotetext{
${ }^{26}$ APT, AmT, sygn. D 2968, Sprawy, k. 129.

${ }^{27}$ Ibid., k. 143.

${ }^{28}$ Ibid., k. 146, Uchwała Rady Miasta Torunia nr 76 z dnia 29 kwietnia 1931 r. o treści: „Rada Miejska przychyla się do uchwały Magistratu w przedmiocie nazwania ulicy od dworca Toruń-Czarnowo (ul. Sienkiewicza) do hali balonowej ulicą Balonową, oraz ulicy poprzecznej od toru kolejowego przy ul. Balonowej wiodącej aż do ul. Grunwaldzkiej, ulicą Redemptorystów".
} 
balonowa została przejęta przez III Batalion Aeronautyczny ${ }^{29}$. Na początku lat pięćdziesiątych XX w. została zdemontowana. Część konstrukcji prawdopodobnie służy obecnie jako nakrycie sztucznego lodowiska w Łodzi. Na mapach pochodzących sprzed 1920 r. teren, na którym stała hala, nosił niemiecką nazwę Luftfahrzeug Hafen, a prowadząca do hali ulica nazywała się Zeppelin Strasse ${ }^{30}$. W 1920 r. ulica zyskała polską nazwę Lotnicza, a teren, na którym zlokalizowana była hala, nazywany był przez pewien czas Lotniskiem. Budynek, w którym „garażowano" sterowiec, nosił nazwy Hala Sterowcowa, Hala Balonowa, Hala Aeronautyczna ${ }^{31}$. W okresie niemieckiej okupacji ulica nosiła nazwę Baltenstrasse ${ }^{32}$. Do przedwojennej nazwy ulicy powrócono po odzyskaniu niepodległości w $1945 \mathrm{r} .{ }^{33}$ Dzisiaj nie ma już pozostałości po obiektach hali balonowej. Ulica Balonowa nie rozpoczyna się jak dawniej przy końcu ulicy Henryka Sienkiewicza, lecz przy ulicy św. Józefa. Ulica Balonowa, dzięki istnieniu tam do połowy dwudziestego wieku tak charakterystycznego obiektu, jakim była wojskowa hala balonowa, na trwałe wpisała się w historię dzielnicy Bielany.

Ulica św. Józefa charakteryzuje się tym, że można ją podzielić na dwie części. Pierwszy odcinek, zaczynający się przy skrzyżowaniu z ulicą Balonową, dochodzi do ulicy Grunwaldzkiej, drugi natomiast rozpoczyna się przy skrzyżowaniu z ulicą Grunwaldzką, a kończy przy Szosie Chełmińskiej w okolicach Dworca Północnego ${ }^{34}$. W trakcie planowania nowego osiedla mieszkaniowego na Bielanach ulica ta stała się ważną arterią komunikacyjną łączącą Przedmieście Bydgoskie z Przedmieściem Chełmińskim. W 1920 r., w ramach polonizacji niemieckich nazw toruńskich ulic, droga ta nie otrzymała swojej urzędowej nazwy.

Nadana uchwałą Rady Miasta Torunia z 29 kwietnia 1931 r. nazwa pierwszego odcinka ulicy: Redemptorystów, ma związek z klasztorem ojców redemptorystów, w skład którego wchodziły obiekty klasztorne,

${ }^{29}$ M. Rusiecki, 80 lat Aeroklubu Pomorskiego, Polska Technika Lotnicza, Materiały historyczne, $\mathrm{nr} 112$ (7/2015) s. 1-5.

${ }^{30}$ APT, AmT, sygn. D 2968, Sprawy, k. 128, niemiecki plan Torunia z 1916 r.

${ }^{31}$ Plany miasta Torunia z 1921 i 1930, zbiory autora.

${ }^{32}$ Strassenverzeichnis, s. 4 i 15.

${ }^{33}$ Plan orientacyjny.

${ }^{34} \mathrm{~W}$ tym czasie ulica Okrężna stanowiła północną administracyjną granicę miasta. 
gimnazjum (które wraz z internatem nosiło nazwę juwenatu), tymczasowa kaplica pod wezwaniem św. Józefa oraz zabudowania gospodarcze. Zespół klasztorny stanowił dominantę tej dzielnicy. Uhonorowanie zakonu ojców redemptorystów nazwą ulicy podkreślało znaczenie klasztoru, świątyni i szkoły dla społeczności tej części miasta.

Drugi odcinek tej drogi (od ulicy Grunwaldzkiej do Szosy Chełmińskiej) Magistrat zaproponował nazwać: Przy Wodociągach ${ }^{35}$. Ostatecznie jednak ten fragment ulicy w tym postępowaniu nie został nazwany.

Dnia 18 czerwca 1931 r. VII Wydział Techniczno-Budowlany Magistratu (powołując się na przytoczone już wcześniej rozporządzenie wojewody pomorskiego o ewidencji i kontroli ruchu ludności ${ }^{36}$ ) opracował zestawienie wszystkich istniejących (nienazwanych) dróg, ulic i placów w obrębie administracyjnym miasta Torunia i skierował do Wydziału III Administracyjnego prośbę o zgłoszenie propozycji ich nazwania $^{37}$. Integralną częścią tego dokumentu jest schematyczny plan Torunia z zaznaczonymi (rzymskimi cyframi) ulicami niemającymi wówczas jeszcze nazwy ${ }^{38}$. Warto tu podkreślić, że w Toruniu w tym czasie istniały 193 ulice $^{39}$, a tylko $148 \mathrm{z}$ nich miało swoją administracyjną nazwę. Czterdzieści pięć toruńskich ulic było nienazwanych, co stanowiło blisko 24 procent wszystkich ulic w mieście. Brak nazw aż tak dużej liczby ulic w mieście stwarzał sytuację, w której mieszkańcom i urzędom trudno było się odnaleźć ${ }^{40}$.

\footnotetext{
${ }^{35}$ APT, AmT, sygn. D 2968, Sprawy, Uchwała Magistratu nr 1145/31, k. 146.

${ }^{36}$ Zob. przypis nr 14.

${ }^{37}$ APT, AmT, sygn. D 2968, Sprawy, k. 168.

${ }^{38}$ Ibid., k. 154.

${ }^{39}$ Ibid., sygn. D 2969, Nazwy ulic, k. 73-76.

${ }^{40}$ Podobnie jak dzisiaj także w dwudziestoleciu międzywojennym adres zamieszkania był istotnym elementem identyfikacji. Dnia 29 listopada 1928 r. minister spraw wewnętrznych wydał rozporządzenie ogłoszone w Dzienniku Ustaw nr 100, poz. 898 $\mathrm{O}$ dowodach osobistych, na podstawie którego każda osoba zamieszkała w gminie mogła żądać za opłatą 60 groszy wydania dowodu osobistego, w którym oprócz innych danych osobowych, takich jak imię, nazwisko, data i miejsce urodzenia, fotografia, znaki szczególne, zawarta była informacja o miejscu zamieszkania. Dnia 16 marca $1928 \mathrm{r}$. prezydent Rzeczypospolitej wydał rozporządzenie (DzU, nr 32 poz. 309) O ewidencji i kontroli ruchu ludności, w którym nałożony został obowiązek meldunkowy ciążący na właścicielu lub dzierżawcy domu w odniesieniu do osób przebywających w miej-
} 
Wśród nienazwanych ulic figurujących w tym zestawieniu było też kilka znajdujących się na obszarze osiedla Bielany. Ulice te opisane zostały następująco: ,Szosa wojskowa od ulicy Grunwaldzkiej do granicy miasta, położona między gruntami wojskowymi i miejskimi” - oznaczona w spisie rzymską liczbą III (dzisiejsza ulica św. Klemensa). „Szosa (część drogi) od ulicy Grunwaldzkiej do dworca Toruń-Północ (grunty miejskie i prywatne). Powyższa droga jest przedłużeniem ulicy Redemptorystów (nazwa ustalona w maju 1931 roku)" - mająca oznakowanie IV (dzisiejsza ulica św. Józefa). „Ścieżka o szerokości 3 metrów od ulicy Grunwaldzkiej, wzdłuż toru kolejowego" - zaznaczona na planie rzymską cyfrą V (dzisiejsza ulica Kaszubska). „Ulica prywatnej spółki osadniczej, od kolei Toruń Czarnowo do Szosy Chełmińskiej (24 prywatnych nieruchomości)" - oznaczona liczbą VI (dzisiejsza ulica Wodociągowa). „Ulica (prywatnej spółki osadniczej) od ulicy Grunwaldzkiej do drogi prywatnej (11 nieruchomości prywatnych)" - oznaczona kolejną liczbą VII (dzisiejsza ulica Borowiacka) ${ }^{41}$.

Pierwszą z wymienionych ulic jest dzisiejsza ulica św. Klemensa. Ponieważ droga stanowiła strategiczny trakt wojskowy (połączenie Szosy Okrężnej z placem ćwiczeń saperów), postulowano, aby w sprawie nadania nazwy dla tej ulicy porozumieć się z wojskiem. Przedstawiono przy tym propozycje następujących nazw: Wojskowa, Jana Rybińskiego, Kręta, Przejazd, św. Klemensa ${ }^{42}$. Ostatecznie przyjęto imię św. Klemensa ${ }^{43}$. Radca wojewódzki Stanisław Dąbrowski ${ }^{44}$ w liście skierowanym do Ottona Steinborna pisał: „Ojcowie Redemptoryści na Bielanach są bardzo wdzięczni za to, że dzięki staraniom Pana Doktora Rada Miejska nazwała jedną z ulic - ulicą św. Klemensa dla uczczenia pamięci Apostoła Warszawy i założyciela polskiej prowincji zakonnej Redemptorystów, który był wybitnym działaczem społecznym" ${ }^{\text {"45 }}$.

scowości dłużej niż 24 godziny. Brak adresu nieruchomości uniemożliwiał zatem realizację praw i obowiązków określonych w tych przepisach.

${ }^{41}$ APT, AmT, sygn. D 2968, Sprawy, k. 168.

${ }^{42}$ Ibid., k. 170.

${ }^{43}$ Ibid., k. 173, Uchwała Rady Miasta nr 151 z dnia 14 sierpnia 1931 r.

${ }^{44}$ Księga adresowa i informacyjna miasta Torunia, oprac. A. Krzyżanowski, Toruń 1932, s. 340

${ }^{45}$ APT, AmT, sygn. D 2968, Sprawy, k. 176. 
Dzisiejszy obraz tej ulicy znacznie różni się od wizerunku z $1931 \mathrm{r}$. Aż do połowy XX w. część tej drogi przecinała ulicę św. Józefa i łączyła się z ulicą Grunwaldzką w okolicach dzisiejszej ulicy Kurpiowskiej. W ten sposób tworzył się charakterystyczny trójkąt, ograniczony ulicami św. Józefa, Grunwaldzką i św. Klemensa. Po drugiej wojnie światowej na tym terenie zbudowano zespół szkół o profilu spożywczym, ekonomicznym i mechaniczno-elektrycznym, a odcinek ulicy św. Klemensa pomiędzy św. Józefa i Grunwaldzką został zlikwidowany. W okresie okupacji niemieckiej ulica otrzymała dwie nazwy: na odcinku od Szosy Okrężnej do św. Józefa została nazwana Karnickelgrund, a fragment od św. Józefa do Grunwaldzkiej - Eulenweg ${ }^{46}$. Od odzyskania w 1945 r. niepodległości aż do 1963 r. na całej długości ulicy funkcjonowała nazwa św. Klemensa, natomiast od 1963 r. istniejący obecnie odcinek ulicy nosił imię Jędrzeja Śniadeckiego, a następnie Jana i Jędrzeja Śniadeckich ${ }^{47}$. Od 25 lutego 2010 r. nazwa ulicy św. Klemensa została przywrócona na całym odcinku (od ulicy św. Józefa aż do Szosy Okrężnej) ${ }^{48}$.

Kolejną ulicą, która otrzymała wówczas nazwę, był bezimienny jeszcze odcinek dzisiejszej ulicy św. Józefa (od skrzyżowania z ulicą Grunwaldzką do Szosy Chełmińskiej). Ze względu na to, że przy ulicy zlokalizowany był Zakład Wodociągowy, zaproponowano nazwę Przy Wodociągach $^{49}$. Pojawił się też postulat, aby tej ulicy nadać omawianą wcześniej nazwę - Redemptorystów ${ }^{50}$. Po raz pierwszy zaproponowano też nazwę św. Józefa ${ }^{51}$. Ostatecznie Rada Miasta (uchwałą z 26 sierpnia 1931 r.) cały ten odcinek, poczynając od ulicy Balonowej aż do Szosy Chełmińskiej, zdecydowała się nazwać ulicą Redemptorystów $^{52}$. Tak jak w przypadku ulicy św. Klemensa na ostateczną nazwę

\footnotetext{
${ }^{46}$ Strassenverzeichnis, s. 5, 7,18.

${ }^{47}$ Spis ulic Torunia sporządzony przez Wydział Geodezji i Kartografii Urzędu Miasta Torunia, Toruń 2018, poz. 22383, w zbiorach autora.

${ }^{48}$ APT, Amt, Uchwała nr 746/2010 Rady Miasta Torunia z dnia 25 lutego 2010 r.

${ }^{49}$ Uchwała Magistratu miasta Torunia nr $1145 / 31$ z dnia 2 czerwca 1931 r., APT, AmT, sygn. D 2968, Sprawy, k. 136 (lewa strona karty).

${ }^{50}$ Ibid., k. 136 (lewa strona karty), Uchwała Magistratu miasta Torunia nr 1126 $\mathrm{z}$ dnia 25 czerwca $1931 \mathrm{r}$.

${ }^{51}$ Ibid., sygn. D 2968, Sprawy uporządkowania, k. 149, 173, 177.

${ }^{52}$ Ibid., k. 173.
} 
(św. Józefa) tej ulicy miał wpływ radca wojewódzki Stanisław Dąbrowski, który w cytowanym wcześniej piśmie skierowanym do Ottona Steinborna pisał: „Ojcowie Redemptoryści na Bielanach [...] otrzymali wiadomość, że druga ulica ma otrzymać nazwę Redemptorystów. Ojcowie w całej swej skromności zakonnej sądzą, że niczym jeszcze nie zasłużyli na takie wyróżnienie. Pragnęliby bardzo i sprawiłoby im to szczerą radość, gdyby tej drugiej ulicy nie nazwano po nich, lecz otrzymała nazwę ul. Św. Józefa. Pokorną swą prośbę zasyłają niniejszym za moim pośrednictwem na ręce Pana doktora, motywując faktem, że przy tej ulicy mieszczą się zakład wychowawczy, klasztor i kościółek, które są wzniesione pod wezwaniem Św. Józefa. [...] Ojcowie uważają przeto, że najodpowiedniej byłoby nazwać tę drugą ulicę zamiast ul. Redemptorystów, ul. Św. Józefa. Prośbę tę uważam za uzasadnioną i dlatego proszę uprzejmie Wielmożnego Pana Doktora, by raczył od siebie w Radzie Miejskiej uzyskać uchwałę, która by tej

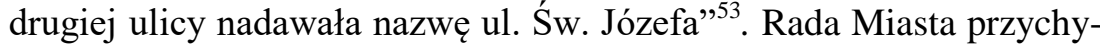
liła się do prośby, ponieważ w wyniku reasumpcji uchwały ulica na całej długości (od Balonowej aż do Szosy Chełmińskiej) zyskała nazwę św. Józefa ${ }^{54}$. W okresie okupacji niemieckiej ulica nosiła nazwę Weisshofer Strasse ${ }^{55}$, a po odzyskaniu w 1945 r. niepodległości przywrócono oryginalną nazwę - św. Józefa ${ }^{56}$.

Następną ulicą wymienioną w zestawieniu z dnia 18 czerwca $1931 \mathrm{r}$. była dzisiejsza ulica Kaszubska ${ }^{57}$. Dla tej drogi postulowano następujące nazwy: Osadnicza, Kaszubska, Przejazd oraz Kraińska ${ }^{58}$. Ostatecznie Rada Miasta postanowiła nazwać tę ulicę Kaszubską ${ }^{59}$. W okresie okupacji niemieckiej ulica przemianowana została na Sperlingsweg ${ }^{60}$.

${ }^{53}$ Zob. przypis nr 45 .

${ }^{54}$ APT, AmT, sygn. D 2968, Sprawy, k. 185, 185 a; zob. też k. 178 - Uchwała nr 201 Rady Miasta z dnia 14 października 1931 r., którą między innymi anuluje się uchwałę Rady Miejskiej z dnia 26 sierpnia 1931 r. nr 151 „,co do nazwy oznaczonych nr IV [...] i nadaje się nową nazwę [...] zamiast Redemptorystów, Św. Józefa”.

${ }^{55}$ Strassenverzeichnis, s. 12 i 18.

${ }^{56}$ Plan orientacyjny.

${ }^{57}$ APT, AmT, sygn. D 2968, Sprawy, k. 168.

${ }^{58}$ Ibid., k.149,168, 170, 171, 177.

${ }^{59}$ Ibid., k. 173, Uchwała Rady Miasta Torunia nr 151 z dnia 26 sierpnia 1931 r

${ }^{60}$ Strassenverzeichnis, s. 11 i 14. 
Po zakończeniu II wojny światowej przywrócono jej pierwotną nazwę - Kaszubska ${ }^{61}$.

Następna ulica z zestawienia ${ }^{62}$ to dzisiejsza ulica Wodociągowa. Zaproponowane zostały nazwy: Przy Wodociągach albo Wodociągowa ${ }^{63}$. Postulowane nazwy okazały się niezwykle trafne, ponieważ w obu propozycjach nazwa określa kierunek do pobliskiego Zakładu Miejskich Wodociągów. Ulica zaczyna się przy torach dawnej linii kolejowej prowadzącej do Czarnowa, a kończy przy Szosie Chełmińskiej. Przecina omawiany kwartał poprzecznie na osi wschód-zachód. Krzyżuje się z ulicami Kaszubską, Borowiacką, Kurpiowską i dochodzi do Szosy Chełmińskiej. W czasie okupacji niemieckiej przyjęła nazwę Kranichweg ${ }^{64}$. Na planie miasta z 1946 r. widnieje już pierwotna nazwa ulicy - Wodociągowa ${ }^{65}$.

Ostatnią ulicą z zestawienia ${ }^{66}$ jest dzisiejsza ulica Borowiacka. W 1926 r. postulowano dla niej nazwę Niecała. Mimo że w 1926 r. istniały przy niej dość liczne zabudowania, to na kilka lat wstrzymano procedurę jej mianowania. Dopiero w 1931 r. ulica zyskała swą nazwę. Padły propozycje: Inwalidów, Borowiacka, Jana Kasprowicza lub Poprzecz$\mathrm{na}^{67}$. Ostatecznie ulica przyjęła nazwę: Borowiacka ${ }^{68}$. W tym czasie była ona znacznie krótsza niż obecnie. Zaczynała się przy ulicy Grunwaldzkiej, a kończyła przy Wodociągowej. Dzisiaj ulica Borowiacka dochodzi aż do ulicy Żwirki i Wigury. W okresie okupacji niemieckiej na całym odcinku była podzielona na dwie części i nosiła dwie nazwy: od Żwirki i Wigury do Wodociągowej ulica nazywała się Finkenschlag, natomiast od ulicy Wodociągowej do Grunwaldzkiej nosiła miano Hasenweg ${ }^{69}$. Po 1945 r. na całej swej długości (od ulicy Grunwaldz-

${ }^{61}$ Plan orientacyjny.

${ }^{62}$ Zob. przypis nr 37

${ }^{63}$ APT, AmT, sygn. D 2968, Sprawy, k. 170.

${ }^{64}$ Strassenverzeichnis, s. 8 i 19.

${ }^{65}$ Plan orientacyjny.

${ }^{66}$ Zob. przypis nr 37.

${ }^{67}$ APT, AmT, sygn. D 2968, Sprawy, k. 170.

${ }^{68}$ Ibid., Sprawy, k. 173.

${ }^{69}$ Strassenverzeichnis, s. 5, 6 i 13. 
kiej aż do Żwirki i Wigury) ulica Borowiacka odzyskała swą pierwotną nazwę ${ }^{70}$.

Dzięki inicjatywie wojewody pomorskiego, działaniom różnych instytucji i organów miejskich, od połowy 1931 r. wszystkie istniejące ulice w Toruniu miały już swoje urzędowe nazwy. Przez kilka następnych lat, aż do czasu opracowania nowego planu zabudowy północnych terenów Torunia, problem nieoznakowanych ulic $\mathrm{w}$ mieście nie pojawiał się.

W latach 1932-1934 pod kierunkiem inż. Ignacego Tłoczka opracowany został nowy plan zabudowy Torunia, który obejmował między innymi północne i zachodnie rejony miasta, w tym również część dzielnicy Bielany ${ }^{71}$ - tu przeznaczony pod zabudowę mieszkaniową teren tworzył nieregularny trójkąt. Od wschodu i zachodu wydzielony kwartał ograniczony był ulicami św. Józefa i Szosą Chełmińską, od południa ulicą Wodociągową, od północy zaś torami kolejowymi biegnącymi od stacji Toruń-Północ, które położone były przy północnej granicy administracyjnej miasta (Szosa Okrężna). Zgodnie z założeniami planu obszar ten przeznaczono pod budownictwo mieszkaniowe o niskiej i gęstej zabudowie. Plan oparty został na wyraźnie zaznaczonej strukturze szachownicy z regularnie powtarzającym się podziałem na niewielkie $\left(500-600 \mathrm{~m}^{2}\right)$ parcele budowlane. Siatka wytyczonych na planie ulic krzyżuje się prostopadle względem siebie, przez co łatwiej było podzielić ten teren na niewielkie parcele budowlane ${ }^{72}$. Od około 1932 r. rozpoczęto realizację wytycznych tego planu. W związku z tym ponownie pojawiło się zagadnienie nazewnictwa zaprojektowanych na tym terenie ulic. Wbrew obowiązującym już wówczas przepisom, jeszcze w 1933 r. ulice nie uzyskały urzędowej nazwy (mimo że zostały już wcześniej definitywnie wytyczone $)^{73}$.

Dnia 2 czerwca 1934 r. do Magistratu wpłynęło pismo Towarzystwa Popierania Budowy Domów Własnych w Toruniu z wnioskiem o nadanie nazw nowo powstałym ulicom ${ }^{74}$. Utworzono komisję składa-

\footnotetext{
${ }^{70}$ Plan orientacyjny.

${ }^{71}$ APT, AmT, sygn. 600, Plan Zabudowy miasta Torunia 1932/34.

72 Ibid., sygn. D 3006, Przydziały, k. 8.

${ }^{73}$ Ibid., sygn. D 2969, Nazwy ulic, k. 53.

${ }^{74}$ Ibid., k. 52.
} 
jącą się z wybitnych osobistości Torunia: Ottona Steiborna, Gwidona Chmarzyńskiego, Zygmunta Mocarskiego oraz inż. Ignacego Tłoczka, której zadaniem było ustalenie nazw dla nowo powstałych ulic osiedla Reja i osiedla Bielany (w rejonie ulicy św. Józefa) ${ }^{75}$. Wkrótce powołano kolejną komisję złożoną z ławników: inż. Kazimierza Ulatowskiego, Stanisława Woydy i Tadeusza Michejdy. Każda z tych komisji postulowała swoje nazwy dla tych ulic $^{76}$. Ostatecznie radni miejscy zatwierdzili część przedłożonych propozycji, jednak w kilku przypadkach zdecydowali się nadać ulicom nazwy całkowicie odmienne od postulowanych przez powołane komisje $\mathrm{e}^{77}$.

Dla dzisiejszej ulicy Józefa Mireckiego (inne zgłoszone propozycje: Zygmunta Działowskiego, Bałtycka) nadano nazwę Montwiłła-Mireckiego. Dla przedłużonej ulicy Borowiackiej zatwierdzono nazwę Borowiacka. Dla dzisiejszej ulicy Stefana Jaracza (inne zgłoszone propozycje: Bronisława Pierackiego, Warmińska) przyjęto nazwę Bronisława Pierackiego. Dla dzisiejszej ulicy Warmińskiej (inne zgłoszone propozycje: Edwarda Donimirskiego, Pałucka) zatwierdzono nazwę Warmińska. Dla przedłużonej ulicy Wybickiego przyjęto nazwę Wybickiego. Dla przedłużonej ulicy Koniuchy zatwierdzono nazwę Koniuchy. Dzisiejszej ulicy Żwirki i Wigury (inne zgłoszone propozycje: Prezydenta Narutowicza, Pomorska) postanowiono nadać nazwę - Żwirki i Wigury.

Proces mianowania tej grupy ulic zakończony został opracowaniem ewidencji, w której wymieniono dwieście ulic istniejących w tym czasie w Toruniu ${ }^{78}$.

Jednocześnie pojawiła się myśl, aby pod tablicami z nazwą niektórych ulic umieścić dodatkową tabliczkę z objaśnieniem jej nazwy. Zaproponowano, aby zostały opracowane krótkie biogramy zawierające podstawowe informacje o życiu, dokonaniach i twórczości osób, których imieniem ulice te nazwano ${ }^{79}$.

\footnotetext{
${ }^{75}$ Ibid., sygn. D 2969, Nazwy ulic, k. 56.

${ }^{76}$ Ibid., sygn. D 2969, k. 58 i 59.

${ }^{77}$ Ibid., k. 60, Uchwała Rady Miasta Torunia nr 136 z dnia 3 października 1934 r.

${ }^{78}$ Ibid., sygn. D 2969, Nazwy ulic, k. 73, 74, 75, 76.

${ }^{79}$ Ibid., k. 61 i 62 . Niestety, pomysł ten nie został zrealizowany. W wielu przypadkach, szczególnie jeśli ulice mają charakter pamiątkowy i zostały utworzone od nazw osobowych (często wrażliwych na zmiany ustrojowe), nadane w ten sposób nazwy
} 
Współczesny wizerunek ulic tej części osiedla Bielany w dużym stopniu różni się od tego, który został zaprojektowany przez zespół inż. Ignacego Tłoczka. Jedynie kwartał znajdujący się w obrębie ulic Wodociągowej, św. Józefa, Szosy Chełmińskiej i Żwirki i Wigury jest zgodny z oryginalnym założeniem. Natomiast teren położony na północ od ulicy Żwirki i Wigury, według planu mający stanowić obszar, na którym wyznaczono największą liczbę parceli budowlanych, dzisiaj wygląda zupełnie inaczej. Z wyjątkiem ulicy Żwirki i Wigury zaplanowane wówczas ulice obecnie są znacznie krótsze niż zakładano, a niektóre $\mathrm{z}$ nich nie zostały nawet wytyczone $\mathrm{w}$ terenie.

Zaprojektowana w tamtym czasie ulica Józefa Mireckiego-Montwiłła rozpoczynała się $\mathrm{w}$ miejscu położonym pomiędzy ulicą Wodociągową a Żwirki i Wigury, przekraczała jej linię, kierując się dalej na północ. Kończyła się przy Szosie Chełmińskiej. Pierwsza oryginalna nazwa ulicy zaproponowana przez Helenę Piskorską brzmiała: Józefa Mireckiego-Montwiłła. Autorka wyjaśniała, że „[...] ulica winna nosić nazwę Mireckiego-Montwiłła, a nie Montwiłła-Mireckiego, gdyż Montwiłł jako pseudonim polityczny, a nie przydomek winien iść na drugim miejscu" ${ }^{\prime 80}$. Powszechnie w literaturze przywołuje się nazwisko bohatera, zaczynając od imienia Józef, następnie przydomka Montwiłł i na końcu nazwiska rodowego - Mirecki ${ }^{81}$. Dlatego trudno się zgodzić z uzasadnieniem przedstawionym przez Helenę Piskorską. Ciekawe, że nazwa ulicy przetrwała nawet przez okres PRL, kiedy to często zmieniano nazwy ulic wywodzące się od nazwisk przedwojennych bohaterów. Prawdopodobnie to, że Józef Montwiłł-Mirecki działał w szeregach partii o nazwie „socjalistyczna" ${ }^{\text {22 }}$ mogło spowodować, że jej nazwa

z biegiem czasu tracą swą informacyjną, pamiątkową i emocjonalną treść, a umieszczenie przy nazwie ulicy tabliczki z krótkim biogramem patrona mogłoby zachować pamięć o bohaterze ulicy. Tabliczka taka mogłaby się w ten sposób przyczynić do odpowiedzi na pytanie: kto jest patronem tej ulicy, a także, czym się zasłużył, aby jego imieniem nazwać właśnie tę ulicę.

${ }^{80}$ Ibid., sygn. D 2969, Nazwy ulic, k. 61.

${ }^{81}$ P. Duber, Józef Montwitt-Mirecki - Ksiażę Rewolucji. W stulecie akcji rogowskiej, Mówią wieki, nr 11(563), 2006; L. Dubacki, Józef Montwilt-Mirecki, Przegląd Socjalistyczny, nr 5 z 2008 r.

82 Józef Montwiłł-Mirecki był działaczem Organizacji Bojowej Polskiej Partii Socjalistycznej. 
nie została w okresie PRL przemianowana. Dzisiejsza ulica Józefa Mireckiego znacznie różni się swym wyglądem od tej, którą zaprojektował zespół inż. Ignacego Tłoczka ${ }^{83}$. Obecnie droga nie przekracza ulicy Żwirki i Wigury. W okresie niemieckiej okupacji ulicę nazwano Um Storchennes ${ }^{84}$. Po 1945 r. powrócono do nazwy MontwiłłaMireckiego ${ }^{85}$. Jeszcze na planie miasta z roku 1949 ulica nosiła nadaną wówczas nazwę. Współcześnie nazwa ulicy brzmi: Józefa Mireckiego. Usunięcie z nazwy oryginalnego pseudonimu „Montwiłł” w dużej mierze ogranicza rozpoznanie jej bohatera i czyni go anonimowym. Uzasadniony może być zatem postulat przywrócenia nadanej wówczas oryginalnej nazwy, która powinna brzmieć: ulica Józefa MontwiłłaMireckiego. Restytuowanie pełnej nazwy tej ulicy przez umieszczenie imienia, przydomka i nazwiska byłoby pewnym minimum edukacyjnym, pozwoliłoby też umiejscowić Józefa Montwiłła-Mireckiego we właściwym czasie i historii ${ }^{86}$.

Następną ulicą, w tym czasie utworzoną, było przedłużenie wcześniej omawianej ulicy Borowiackiej ${ }^{87}$. Zaprojektowana droga łączyła się $\mathrm{z}$ istniejącym odcinkiem ulicy Borowiackiej w miejscu skrzyżowania z ulicą Wodociągową. Dalej ulica kierowała się na północ, przekraczała ulicę Żwirki i Wigury i kończyła na planowanym przedłużeniu ulicy Koniuchy. W roku 1994 odcinek ulicy od Żwirki i Wigury nazwany został imieniem Janiny Hurynowicz ${ }^{88}$.

Kolejną z katalogu nominowanych wówczas była ulica Bronisława Pierackiego (obecna ulica Stefana Jaracza), której nazwę ustalono dla

\footnotetext{
${ }^{83}$ APT, AmT, sygn. D 600, Plan zabudowy, bez paginacji, akta luźne. Wśród luźnych akt znajduje się tabela datowana 21 marca 1934 r. z nazwiskami pracowników zatrudnionych przy sporządzaniu planu zabudowy miasta Torunia. W skład zespołu wchodziło 9 osób: inż. Ferdynard Roth, inż. Ignacy Tłoczek, inż. Stefan Pietrzak, technik mierniczy Dymitr Iwanow, technik mierniczy Leon Biernacki, mierniczy Marian Rumowski, mierniczy Piotr Wróblewski, kreślarz Władysław Ćwikliński oraz kreślarz Tadeusz Wojciechowski.

${ }^{84}$ Strassenverzeichnis, s. 16.

${ }^{85}$ Plan orientacyjny.

${ }^{86} \mathrm{~K}$. Wojtczuk, Nazwy ulic i osiedli siedleckich $w$ świetle analizy językoznawczej, Szkice Podlaskie, nr 6, r. 1998, s. 45.

${ }^{87}$ Zob. przypisy $67-70$.

${ }^{88}$ APT, Amt, Uchwała Rady Miasta Torunia nr 422/94 z dnia 31 marca 1994 r.
} 
upamiętnienia zamordowanego w dniu 15 czerwca 1934 r. ministra spraw wewnętrznych. Ulicę zaprojektowano jako drogę biegnącą równolegle do Szosy Chełmińskiej. Do 1939 r. częściowo zabudowano tylko odcinek drogi pomiędzy ulicą Żwirki i Wigury a ulicą Wodociągową. Natomiast po północnej stronie Żwirki i Wigury ulica nigdy nie została zagospodarowana zgodnie z założeniem przyjętym przez zespół inż. Ignacego Tłoczka. W latach sześćdziesiątych XX w. na tym terenie powstały placówki edukacyjne $\mathrm{i}$ wielorodzinne domy mieszkalne. W latach siedemdziesiątych XX w. odcinek leżący pomiędzy ulicą Wodociągową i Józefa Wybickiego został odłączony od ulicy Stefana Jaracza i nazwany - Kurpiowska ${ }^{89}$. Obecnie ulica Stefana Jaracza stanowi zaułek i ma około 150 metrów.

Ciekawa jest historia nazw, jakie ulica przez cały ten okres otrzymywała. Po wkroczeniu Niemców do Torunia została zmieniona na Schwalbenweg $^{90}$. W 1945 r. przywrócono pierwotną, oryginalną nazwę Bronisława Pierackiego ${ }^{91}$, która przetrwała do $1951 \mathrm{r}$. W latach 1951-1956 patronem ulicy był Julian Nowicki, którego imieniem nazwano potem odcinek Szosy Chełmińskiej ${ }^{92}$. Od 29 maja 1956 r. ulica przyjęła imię Stefana Jaracza ${ }^{93}$. Można tylko przypuszczać, że przemianowanie w 1951 r. ulicy Bronisława Pierackiego na Juliana Nowickiego nastąpiło z pobudek politycznych. Ofiara sanacyjnej przedwojennej policji - Julian Nowicki - z pewnością był patronem bliższym socjalistycznym wzorcom niż przedwojenny sanacyjny minister spraw wewnętrznych.

Ulica Warmińska zaczynała się przy ulicy Wodociągowej, a kończyła na nienazwanej w tym czasie drodze (obecnie jest to przedłużenie ulicy Długiej). Podobnie jak omawiane wcześniej ulice tego kwartału tylko odcinek na południe od ulicy Żwirki i Wigury został zabudowany zgodnie z założeniem, natomiast północny odcinek nigdy nie został zrealizowany w sposób przewidziany w planie Ignacego Tłocz-

\footnotetext{
${ }^{89}$ Ibid., Uchwała Rady Miasta Torunia nr V/22/74 z dnia 29 listopada 1974 r.

${ }^{90}$ Strassenverzeichnis, s. 10 i 13.

${ }^{91}$ Plan orientacyjny.

${ }^{92}$ Spis ulic Torunia sporządzony przez Wydział Geodezji, $\mathrm{nr} 7240$.

${ }^{93}$ APT, AmT, Uchwała Rady Miasta Torunia nr III/12/56 z 29 maja 1956 r.
} 
ka. W okresie niemieckiej okupacji ulica przyjęła miano Umselweg ${ }^{94}$. Po 1945 r. ulica Warmińska odzyskała swą pierwotną nazwę ${ }^{95}$. Obecnie ulica Warmińska jest ślepym zaułkiem o długości około 150 metrów. Rozpoczyna się w okolicy ulicy Wodociągowej i kończy na styku z ulicą Żwirki i Wigury.

Zaplanowane przedłużenie ulicy Koniuchy w rzeczywistości nigdy nie zostało zrealizowane. Przed rokiem 1920 niemiecka nazwa tej ulicy brzmiała Rossgartenstrasse ${ }^{96}$. Łączyła ona Szosę Chełmińską z ulicą Grudziądzką i była najbardziej na północ położoną drogą w tym rejonie miasta. W okresie niemieckiej okupacji ulica ponownie została przemianowana na Rossgartenstrasse ${ }^{97}$, aby w 1945 r. powrócić do swej polskiej nazwy - Koniuchy ${ }^{98}$.

Przedłużenie ulicy Józefa Wybickiego to odcinek drogi biegnącej od Szosy Chełmińskiej do ulicy Borowiackiej. Podobnie jak w przypadku wymienionych już ulic tego osiedla wzdłuż ulicy Józefa Wybickiego zaplanowano budownictwo jednorodzinne. Północną stronę ulicy zabudowano zgodnie z założeniem, natomiast południowa strona zarezerwowana została dla planowanej trasy Wschód-Zachód. W okresie okupacji niemieckiej ulica Józefa Wybickiego przyjęła niemiecką nazwę Laengnerstrasse ${ }^{99}$. Po roku 1945 powrócono do przedwojennej polskiej nazwy - Józefa Wybickiego ${ }^{100}$.

Ostatnią z nazwanych wówczas ${ }^{101}$ była ulica Żwirki i Wigury. Arteria miała być jedną $\mathrm{z}$ ważniejszych dróg łączących ulicę Legionów z ulicą św. Józefa. Wzdłuż odcinka od Szosy Chełmińskiej do ulicy św. Józefa miały powstać budynki kilkupiętrowe. Ostatecznie jednak tylko południowa strona ulicy zabudowana została zgodnie z planem, natomiast przy północnej stronie odcinka tej ulicy od połowy lat pięćdziesiątych zaczęły powstawać obiekty szkolne.

\footnotetext{
${ }^{94}$ Strassenverzeichnis, s. 18.

${ }^{95}$ Plan orientacyjny.

${ }^{96}$ APT, AmT, sygn. D 2967, Przemalowanie, bez paginacji.

${ }^{97}$ Strassenverzeichnis, s. 10 i 14.

${ }^{98}$ Plan orientacyjny.

${ }^{99}$ Strassenverzeichnis, s. 8 i 19.

${ }^{100}$ Plan orientacyjny.

${ }^{101}$ Zob. przypis nr 77.
} 
Patronem tej ulicy miał zostać prezydent Gabriel Narutowicz ${ }^{102}$. Jednak ze względu na opór prawicowych radnych miasta Torunia, niechętnych pierwszemu prezydentowi Rzeczypospolitej, nie dopuszczono do nadania imienia prezydenta Gabriela Narutowicza nowo powstałej ulicy. Przyjęto imiona dwóch patronów: Żwirki i Wigury ${ }^{103}$.

Ustanowiona wówczas nazwa ulicy Żwirki i Wigury zamiast postulowanej - Prezydenta Narutowicza - zachowała się do dnia dzisiejszego, natomiast prezydent Gabriel Narutowicz praktycznie do dzisiaj nie został uhonorowany w Toruniu ulicą swojego imienia. Jak dotychczas jedynym działaniem mającym na celu mianowanie ulicy jego imieniem w Toruniu jest uchwała Rady Miasta Torunia „,w sprawie nadania nazw dla nowo projektowanych ulic na osiedlu Podgórz oraz korekty ulicy Letniej”" ${ }^{104}$. Uchwała wskazuje lokalizację nowej ulicy tuż za Szkołą Podstawową nr 15, na Podgórzu, w bok od ulicy Jana Paderewskiego, na gruntach prywatnych. Pomijając już fakt, że do dnia dzisiejszego uchwała $\mathrm{w}$ tym zakresie nie została wykonana, to miejsce $\mathrm{i}$ wizerunek projektowanej ulicy (boczny zaułek o długości około 90 metrów) wydają się co najmniej niewystarczające dla uhonorowania pierwszego w odrodzonej Rzeczypospolitej prezydenta Polski.

Warto w tym miejscu wymienić choćby najważniejsze instytucje i osoby, które w tamtym czasie zaangażowane były w oznaczanie ulic, a także spróbować ustalić przyczyny, które powodowały tak dhugotrwały proces nazewnictwa. Zgodnie $\mathrm{z}$ obowiązującymi $\mathrm{w}$ tym czasie przepisami, samorządy miast nie tylko były uprawnione, ale wręcz zobowiązane do nazywania dróg, ulic i placów w miastach. Wynikało to choćby z wymienionego już wcześniej rozporządzenia wojewody pomorskiego z dnia 12 maja 1931 r. (o ewidencji i kontroli ruchu ludności), które nakładało na korporacje miejskie obowiązek nadawania nazw wszystkim ulicom i placom publicznym równocześnie (co warto jeszcze raz podkreślić) z definitywnym ich wytyczeniem. Jak można zatem przypuszczać, to po stronie władz miasta Torunia leżały inicjatywa i urzędowe czynności nakierowane na bieżące, systematyczne i terminowe

102 APT, AmT, sygn. D 2969, Nazwy ulic, k. 58.

${ }^{103}$ Ibid., k. 60, Uchwała Rady Miasta Torunia nr 136 z dnia 3 października 1934 r.

${ }^{104}$ Ibid., Uchwała Rady Miasta Torunia nr 497/2000 z 27 lipca 2000 r. 
nazywanie wszystkich istniejących, nienazwanych i nowo powstałych ulic w mieście.

$\mathrm{Z}$ analizy dokumentów zgromadzonych w Archiwum Państwowym w Toruniu wynika, że władze wielokrotnie bagatelizowały konieczność regularnego i niezwłocznego oznakowania ulic, co rodziło liczne problemy. Często powodowało to uzasadnione niezadowolenie i rozgoryczenie mieszkańców miasta. Na podstawie wyznaczania nazw dla ulic Borowiackiej i św. Józefa można ocenić, że postępowanie w przypadku nadawania nazw tym ulicom trwało aż pięć lat. Inicjatywa powstała bowiem w 1926 r., a ostateczne nazwy nadano dopiero w 1931 r. W międzyczasie bez żadnego uzasadnienia procedura była kilkakrotnie zawieszana.

Z opisów ulic osiedla Bielany: „ulica [...], przy której jest 24 prywatnych nieruchomości, albo ulica [...], przy której jest 11 nieruchomości prywatnych", wynika, że część z nich miała już wtedy dość liczną zabudowę $^{105}$. W spisie adresowym miasta Torunia z 1932 r. zawarta jest informacja, że przy ulicy Borowiackiej istniało wówczas 14 domów, które zamieszkiwały 42 osoby, natomiast przy ulicy Wodociągowej zbudowano 25 domów zamieszkanych przez 88 dorosłych osób ${ }^{106}$. Wnioskować można, że wymienione w tym opisie domy zostały zbudowane już po wytyczeniu ulic, a przed zatwierdzeniem ich nazw przez Radę Miasta. Przez pewien czas zatem domy te nie tylko nie miały adresu, ale też numeru budynku, co niewątpliwie utrudniało życie ich mieszkańcom. Jak się wydaje, władze miasta nie nadążały za tak szybkim rozwojem budownictwa mieszkaniowego, dlatego pewna część ulic w mieście (pomimo intensywnej już wówczas zabudowy) nawet przez kilka lat nie miała podstawowego administracyjnego oznakowania, jakim jest urzędowa nazwa ulicy i numer porządkowy domu.

Do nadawania nazw toruńskim ulicom powoływane były komisje i komitety złożone $\mathrm{z}$ radnych, urzędników Wydziału Muzealnego, Oświaty i Kultury, decernentów, radców miejskich, a nawet wojewódzkich. Główną rolę odgrywał tu wspomniany już wcześniej dr Otton Steinborn. Poza tym do komisji powoływani byli członkowie Magi-

\footnotetext{
${ }^{105}$ Ibid., sygn. D 2969, Sprawy, k. 170.

${ }^{106}$ Ksiega adresowa, s. 118 i 304.
} 
stratu: prezydent Antoni Bolt, inż. Kazimierz Ulatowski, inż. Ignacy Tłoczek, Helena Piskorska, Zygmunt Mocarski, inż. Ferdynand Roth, a także Kazimierz Esden-Tempski, Stefan Michałek, Tadeusz Michejda, radny wojewódzki Stanisław Dąbrowski i wiele innych osób ${ }^{107}$. Angażowanie w nazewnictwo ulic aż tak wielu różnych instytucji i osób, organizowanie spotkań, konferencji, posiedzeń, wymiana korespondencji, niewątpliwie znacznie przedłużało procedurę nadawania nazw toruńskim ulicom.

Padające ze strony różnych organów władz miasta propozycje nazw pozbawione były często wyraźnej motywacji, co można uzasadnić brakiem przemyślanego i uzgodnionego programu w tej kwestii, przykładem mogą być postulaty nadania nazwy Warmińska dwóm leżącym obok siebie ulicom. Dotyczy to ulicy, którą ostatecznie nazwano imieniem Bronisława Pierackiego (propozycje: Warmińska, Bronisława Pierackiego), oraz Warmińskiej (propozycje: Edwarda Donimirskiego, Pałucka, Warmińska). Poza tym odnotować można niezwykle liczne propozycje dla pozostałych ulic tego osiedla, np. dla ulicy Żwirki i Wigury (propozycje: Prezydenta Narutowicza, Pomorska, Żwirki i Wigury), Józefa Mireckiego (propozycje: Zygmunta Działowskiego, Bałtycka, Józefa Mireckiego-Montwiłła), Kaszubska (propozycje: Osadnicza, Kaszubska, Przejazd, Kraińska), św. Klemensa (propozycje: Wojskowa, Jana Rybińskiego, Kręta, Przejazd, św. Klemensa), św. Józefa (propozycje: Przy Wodociągach, Redemptorystów, Sienkiewicza, Fryderyka Skarbka, Saperów, św. Józefa), Borowiacka (propozycje: Niecała, Inwalidów, Jana Kasprowicza, Poprzeczna, Borowiacka).

Analizując proces nazewnictwa toruńskich ulic można zauważyć, że proponowane w tym czasie nazwy były w kilku przypadkach wynikiem politycznej dominacji ówczesnych decydentów. W toruńskiej Radzie Miasta w dwudziestoleciu międzywojennym większość stanowili przedstawiciele stronnictw prawicowych, będących politycznymi przeciwnikami ugrupowań sanacyjnych ${ }^{108}$. Przez cały ten okres na

\footnotetext{
${ }^{107}$ APT, AmT sygn. D 2968, Sprawy, k. 129,143, 146, 168-171, 173, 176, 177; ibid., sygn. D 2969, Nazwy ulic, k. 23-25, 36, 49, 52, 56-62, 64.

${ }_{108}$ M. Wojciechowski, Życie polityczne Torunia w latach 1920-1939, [w:] Historia Torunia, t. III, cz. II, s. 149.
} 
politycznej scenie miasta toczyły się zaciekłe walki pomiędzy ugrupowaniami prawicowymi i sanacyjnymi. Aż do zamachu majowego przewage miała Narodowa Partia Robotnicza i jej sprzymierzeńcy. Politycznym zapleczem sanacji był natomiast wojewoda, który realizował politykę osłabiania wpływów prawicy w mieście, a więc endecji $\mathrm{i} \mathrm{NPR}^{109}$. W konsekwencji w Toruniu, w odróżnieniu od wielu innych miast, nie było ulic, których patronami byli przedstawiciele władz sanacyjnych ${ }^{110}$. Pomimo przedłożenia kilku wniosków, radni miasta nie dopuścili do nazwania ulicy imieniem Marszałka Józefa Piłsudskiego, jednoznacznie utożsamianego z sanacją. Bez wątpienia konsekwencją odmowy przemianowania w 1928 r. ulicy Jagiellońskiej na ulicę Marszałka Józefa Piłsudskiego ${ }^{111}$ było rozwiązanie w 1929 r. Rady Miasta ${ }^{12}$. Oficjalnym pretekstem było wykrycie nieprawidłowości, jakie wykazała zarządzona przez wojewodę lustracja organów samorządowych Torunia ${ }^{113}$. Znany i szeroko wówczas komentowany

${ }^{109}$ T. Cieślak, Etapy rozwoju miasta Torunia w XIX $i$ XX wieku, Rocznik Toruński, t. 15: 1980, s. 249.

${ }^{110}$ APT, AmT, sygn. D 1407, Uchwały Rady Miasta za lata 1927/1931, uchwała nr 340 z dnia 7 listopada 1928 r.; ibid., sygn. D 1118, Posiedzenia Rady Miejskiej, sprawozdania do Województwa, k. 433, 434, 445; ibid., sygn. D 1403, Rozwiązanie i wybory Rady Miejskiej 1929, wniosek o nadanie jednej z głównych ulic w Toruniu nazwy Marszałka Józefa Piłsudskiego, k. 9, 10, 11. Jedynym wyjątkiem może być tu osoba Bronisława Pierackiego. Patronem ulicy został bowiem zamordowany w trakcie pełnienia obowiązków konstytucyjny minister, którego imieniem wówczas nazwano ulice w wielu miastach Rzeczypospolitej.

${ }^{111}$ Wniosek Komitetu Obchodu 10-lecia Niepodległości Polski z dnia 24 października 1928 r., APT, AmT, sygn. D 1118, k. 9, oraz wniosek z dnia 23 grudnia 1933 r. Związku Weteranów Powstań Narodowych z lat 1914-1919, Koło w Toruniu, skierowany do Rady Miasta, o nadanie jednej z głównych ulic miasta Torunia nazwy „ulica Marszałka Józefa Piłsudskiego”, ibid., sygn. D 2969, Nazwy ulic, k 49, 50. Rada Miasta Torunia odmówiła nadania nazwy jednej z głównych ulic miasta imienia Marszałka Józefa Piłsudskiego, odmówiła także nadania honorowego obywatelstwa Marszałkowi Józefowi Piłsudskiemu, dopiero po śmierci Marszałka (14 maja 1935 r.) nadano mu honorowe obywatelstwo miasta Torunia.

112 APT, AmT, sygn. D 1403, Rozwiązanie, k. 484, 485; ibid., sygn. D 1118, Posiedzenia, k. 9, 10, 11, 49, 50, 459; ibid., sygn. D 1777, Księga adresowa miasta Torunia, t. I, k. 8, 9, 43, 44, 45, 46; ibid., sygn. D 1112, Skład Rady Miejskiej, k. 31, 32, 72, 73.

${ }_{113}$ A. Tarnowska, Niegospodarność czy echa wielkiej polityki, Zapiski Historyczne, t. 80: 2015, z. 1, s. 26. 
był proces wytoczony jednemu z prominentnych endeckich działaczy, adwokatowi Stanisławowi Woydzie, który w artykule zamieszczonym w „Słowie Pomorskim”" 114 oskarżał władze centralne o to, że wyłączną przyczyną rozwiązania w 1929 r. toruńskiej Rady Miasta była odmowa nadania jednej z ulic Torunia imienia Marszałka Józefa Piłsudskiego.

$\mathrm{Z}$ powyższego przykładu wynika, że toczona $\mathrm{w}$ dwudziestoleciu międzywojennym walka polityczna przenosiła się również na obszar nazewnictwa toruńskich ulic. Potrzeba wyrażenia politycznej dominacji w oznaczaniu miejskiej przestrzeni była dla ówczesnych sił politycznych istotniejsza niż próba stworzenia miejskiego nazewnictwa jako systemu niepodlegającego doraźnym i koniunkturalnym wpływom. Systemu, wokół którego buduje się tradycje i tworzy historię. Nazewnictwo ulic spełnia bowiem nie tylko swą administracyjną funkcję, ale dodatkowo zawiera przymiot kultury. Realizacji takiej idei niewątpliwie sprzyja przemyślane i tematyczne nadawanie nazw ulicom, drogom, placom i osiedlom w miastach.

\section{Bibliografia}

\section{Źródła}

Archiwum Państwowe w Toruniu, Akta miasta Torunia: sygn. D 600, Plan zabudowy miasta Torunia 1932/34.

sygn. D 1112, Skład Rady Miejskiej, 28.VIII.1931 - 30.VI.1934.

sygn. D 1118, Posiedzenia Rady Miejskiej, sprawozdania do Województwa.

sygn. D 1331, Wydział prezydialny.

sygn. D 1403, Rozwiązanie i wybory Rady Miejskiej rok 1929.

sygn. D 1407, Uchwały Rady Miasta za lata 1927/1931.

sygn. D 1777, Księga adresowa miasta Torunia, t. 1.

sygn. D 2900, Sprawozdania o ruchu budowlanym.

sygn. D 2902, Statystyka ruchu budowlanego, t. VIII.

sygn. D 2967, Przemalowanie nazw niemieckich na polskie.

sygn. D 2968, Sprawy uporządkowania nazw ulic, placów i dróg, oraz numerów orientacyjnych w obrębie miasta Torunia.

sygn. D 2969, Nazwy ulic, placów i numery orientacyjne, t. II.

sygn. D 2988, Sprzedaż gruntów pod budowę domów mieszkalnych, t. IV.

${ }^{114}$ Słowo Pomorskie, nr 266, 269, 270, 276, 17-29 XI 1929 r. 
sygn. D 3006, Przydziały gruntu, Osiedle wojskowe.

sygn. D 3010, Przydziały gruntu, Stowarzyszenie popierania budowy domów dla pracowników umysłowych.

sygn. E 749, Strassennamenverzeichnis.

sygn. G 1218, Klasztor Redemptorystów Św. Józefa.

Akty prawne:

Dziennik Ustaw Rzeczypospolitej Polskiej, nr 42, z dnia 9 maja 1927 r.

Dziennik Ustaw Rzeczypospolitej Polskiej, nr 100, z dnia z dnia 28 grudnia $1928 \mathrm{r}$.

Dziennik Ustaw Rzeczypospolitej Polskiej, nr 32, z dnia 16 marca 1928 r.

Pomorski Dziennik Urzędowy, nr 11, z dnia 1 czerwca 1931 r.

Źródła kartograficzne:

Plan miasta Torunia z $1901 \mathrm{r}$.

Plan miasta Torunia z $1921 \mathrm{r}$.

Plan miasta Torunia z $1929 \mathrm{r}$.

Plan miasta Torunia z $1930 \mathrm{r}$.

Plan orientacyjny miasta Torunia z 1946 r.

Plan miasta Torunia z $1949 \mathrm{r}$.

Literatura:

Cieślak T., Etapy rozwoju miasta Torunia w XIX i XX wieku, Rocznik Toruński, t. 15: 1980.

Duber P., Józef Montwitt-Mirecki - Książę Rewolucji. W stulecie akcji rogowskiej, Mówią wieki, nr 11(563), 2006.

Dubacki L., Józef Montwitt-Mirecki, Przegląd Socjalistyczny, nr 5/2008 r.

Handke K., Polskie nazewnictwo miejskie, Warszawa 1992.

Handke K., Semantyczne i strukturalne typy nazw ulic Warszawy, WrocławWarszawa 1970.

Księga adresowa i informacyjna miasta Torunia, oprac. A. Krzyżanowski, Toruń 1932.

Niedzielska M., Życie polityczne i kulturalne Torunia (1815-1914), [w:] Historia Torunia, pod red. M. Biskupa, t. III, cz. I: W czasach zaboru pruskiego (1793-1920), Torun 2003.

Nowy spis ulic miasta Torunia 1920, Toruń 1920.

Przybyszewski K., Rozbudowa miasta Torunia $w$ latach 1920-1939, Acta Universitatis Nicolai Copernici, Historia XI - Nauki Humanistyczno-Społeczne, z. 74, 1977. 
Rusiecki M., 80 lat Aeroklubu Pomorskiego, Polska Technika Lotnicza, Materiały historyczne, nr $112(7 / 2015)$.

Salm J., Przemiany przestrzenne polskiego Torunia, [w:] Historia Torunia, t. III, cz. I, pod red. M. Biskupa, Toruń 2003.

Spis ulic miasta Torunia sporządzony przez Wydział Geodezji i Kartografii Urzędu Miasta Torunia, Torun 2018.

Strassenverzeichnis der Stadt Thorn, Thorner Freiheit, 1940.

Sudziński R., Społeczeństwo międzywojennego Torunia, [w:] Historia Torunia, t. III, cz. II: W czasach Polski Odrodzonej i okupacji niemieckiej (1920-1945), pod red. M. Biskupa, Torun 2006.

Sudziński R., Infrastruktura i gospodarka komunalna międzywojennego Torunia, [w:] Historia Torunia, t. III, cz. II, pod red. M. Biskupa, Torun 2006.

Tarnowska A., Niegospodarność czy echa wielkiej polityki? Kazus rozwiąania Rady Miejskiej w Toruniu w 1929 roku, Zapiski Historyczne, t. 80: 2015, z. 1 .

Wojciechowski M., Przejęcie Torunia przez władze polskie w styczniu 1920 roku, [w:] Historia Torunia, t. III, cz. II, pod red. M. Biskupa, Toruń 2006.

Wojciechowski M., Życie polityczne Torunia w latach 1920-1939, [w:] Historia Torunia, t. III, cz. II, pod red. M. Biskupa, Toruń 2006.

Wojtczuk K., Nazwy ulic i osiedli siedleckich $w$ świetle analizy językoznawczej, Szkice Podlaskie, nr 6, 1998.

Zieliński P., Rola Torunia i Pomorza w okresie interwencjonizmu państwowego 1936-1939 w świetle publicystyki, Rocznik Toruński, t. 40: 2013.

Żuraszek-Ryś I., Jak powstały nowe nazwy ulic w powojennej Zielonej Górze?, Poznańskie Studia Polonistyczne, t. 19 (39), z. 1, Poznań 2012.

Streszczenie: W artykule poruszona została problematyka nazewnictwa ulic toruńskiej dzielnicy Bielany w dwudziestoleciu międzywojennym. Autor artykułu przedstawił proces nadawania nazw ulicom Torunia, poczynając od $1920 \mathrm{r}$., kiedy to po raz pierwszy w historii miasta ulice otrzymały wyłącznie polskie nazwy. Szczegółowo omówiony został proces nazewnictwa, wymienione zostały najważniejsze instytucje, organy i osoby biorące w nim udział, przesłanki, którymi kierowano się w procesie nazewnictwa, akty prawne i dokumenty. Autor zarysował polityczne, gospodarcze i społeczne tło tego procesu, przedstawił czynniki sprzyjające rozwojowi miasta w okresie 1920-1939, zaprezentował powstanie nowych dzielnic mieszkaniowych, a także proces tworzenia nowych ulic. Praca ukazuje także problemy mieszkańców nowo utworzonych 
dzielnic, związane $\mathrm{z}$ nieuporządkowaną przestrzenią miasta, brakiem nazw ulic i numeracji domów. Artykuł oparty został na materiałach źródłowych zgromadzonych w Archiwum Państwowym w Toruniu. Wykorzystane zostały także opracowania autorów zajmujących się toponomastyką przestrzeni miejskiej, w tym prace Kwiryny Handtke i Krzysztofa Mikulskiego. Artykuł zawiera też wiele wniosków, które narodziły się w trakcie prowadzonych badań. Większość polskich miast może wykazać się opracowaniami naukowymi dotyczącymi tematyki nazewnictwa przestrzeni miejskiej. Jak dotychczas nie ukazało się opracowanie tej problematyki dla Torunia. Prezentowany artykuł stanowić może zatem przyczynek do podjęcia dalszych badań nad historią toruńskich ulic nie tylko w dwudziestoleciu międzywojennym, ale także w końcu XVIII i XIX w., okresie okupacji, latach 1945-1989 oraz czasach współczesnych.

\title{
Creating the names of the streets in Torun's district of Bielany in the interwar period
}

\begin{abstract}
The article addresses the problem of the names of the streets in Torun's district of Bielany in the interwar period. The author of the article presented the process of naming Torun's streets starting from 1920, when for the first time in the history of the town the streets received Polish names. The process of conferring names was discussed thoroughly. The article mentions the most important institutions, bodies and people taking part in the process along with the prerequisites determining the process of naming the streets, legal acts and documents. The author outlines the political, economic and social background of the process. The author also presents factors determining the development of the town in the years 1920-1939, the creation of new residential districts, the process of establishing new streets. The work reveals the problems of inhabitants of newly created districts, which were connected with the chaotic city space, a lack of names of streets and numbers of houses. The article includes many conclusions which were the fruit of the research. Most Polish towns have scientific studies concerning the process of naming streets in the municipal space. However, this is the first study of this kind referring to Torun. The presented article may constitute a contribution to further research on the history of the streets of the town not only in the interwar period, but also at the end of the $18^{\text {th }}$ and $19^{\text {th }}$ centuries, the times of the German occupation, the years 1945-1989 and nowadays.
\end{abstract}




\section{Die Benennung von Straßen in der Thorner Siedlung Bielany in der Zwischenkriegszeit}

Zusammenfassung: Der Artikel behandelt das Thema der Benennung von Straßen im Thorner Stadtteil Bielany (Weißhof) in der Zwischenkriegszeit. Der Autor zeigt, wie den Straßen von Thorn ab 1920 Namen gegeben wurden, als zum ersten Mal in der Geschichte der Stadt die Straßen ausschließlich polnische Namen erhielten. Vor allem geht es um den Prozess der Namensgebung, wobei die wichtigsten Institutionen, Organe und Personen genannt werden, die an diesem Vorgang teilnahmen, ebenso die Grundsätze, von denen man sich beim Prozess der Namensgebung leiten ließ, die Rechtsakte und die Dokumente. Der Autor zeichnet den politischen, wirtschaftlichen und gesellschaftlichen Hintergrund dieses Prozesses, er stellt die Faktoren vor, die die Entwicklung der Stadt zwischen 1920 und 1939 beeinflussten, er zeigt die Entstehung neuer Wohnviertel und auch den Vorgang der Schaffung neuer Straßen. Die Arbeit geht auch auf die Probleme der Bewohner in den neugeschaffenen Vierteln ein, wo der städtische Raum noch nicht geordnet war und Namen von Straßen und Hausnummern fehlten. Der Artikel enthält auch viele Schlussfolgerungen, die sich im Verlauf der Forschungen ergeben haben. Für die meisten polnischen Städte gibt es bereits wissenschaftliche Arbeiten zum Thema der Benennung des städtischen Raums, bisher ist aber keine Arbeit zu dieser Frage für die Stadt Thorn erschienen. Der vorliegende Artikel kann also ein Anstoß zur Aufnahme weiterer Forschungen zur Geschichte der Straßen in Thorn sein, nicht nur in der Zwischenkriegszeit, sondern auch am Ende des 18. und im 19. Jahrhundert, in der Zeit der deutschen Besatzung, in den Jahren 1945-1989 und in der Gegenwart.

Słowa kluczowe: Toruń, toruński, Bielany, 1920 rok, ulica, polskie nazwy, św. Józefa, św. Klemensa, Żwirki i Wigury, Montwiłła-Mireckiego, Narutowicza, Borowiacka, Kaszubska, Balonowa, Pierackiego, Redemptoryści, Warmińska, Lotnicza, Wodociągowa, Grunwaldzka

Keywords: Toruń, of Torun, Bielany, 1920, street, Polish names, św. Józefa, św. Klemensa, Żwirki i Wigury, Montwiłła-Mireckiego, Narutowicza, Borowiacka, Kaszubska, Balonowa, Pierackiego, Redemptoryści, Warmińska, Lotnicza, Wodociągowa, Grunwaldzka

Schlüsselwörter: Bielany (Weißhof), 1920, Straße, polnische Namen, św. Józefa, św. Klemensa, Żwirki i Wigury, Montwiłła-Mireckiego, Narutowicza, Borowiacka, Kaszubska, Balonowa, Pierackiego, Redemptoryści, Warmińska, Lotnicza, Wodociągowa, Grunwaldzka 